\title{
The Effect of Conducting De Bono's Six Thinking Hats Activity on Developing Paragraph Writing Skills of University Students in The Kingdom of Saudi Arabia
}

\author{
Bala Chatta Swamy ${ }^{1}$, Mohammad Imdadul Haque ${ }^{1}$, Venugopal Koppada ${ }^{1} \&$ Nannapaneni Siva Kumar ${ }^{1}$ \\ ${ }^{1}$ College of Business Administration, Prince Sattam Bin Abdulaziz University, Al Kharj, Saudi Arabia \\ Correspondence: Bala Chatta Swamy, Department of Management, College of Business Administration, Prince \\ Sattam Bin Abdulaziz University, Al Kharj, Saudi Arabia. E-mail: balaswamycss@gmail.com
}

Received: May 21, 2019 Accepted: September 12, 2019 Online Published: October 28, 2019

doi:10.5539/ijel.v9n6p186 URL: https://doi.org/10.5539/ijel.v9n6p186

\begin{abstract}
The purpose of the present study is to examine the effect of conducting De Bono's six thinking hats activity on developing the paragraph writing skills of university students. Two groups of students studying the course Technical Writing in Business (NAJM 167) of Prince Sattam Bin Abdulaziz University were chosen to achieve this objective. Pre- and post-tests were conducted for both the groups to determine the difference in their mean scores. Both the groups were given the task of writing a paragraph as a pre-test before conducting the activity. Then, in the experiment section, six thinking hats activity was conducted six times, each time changing the hat color of the groups. As the students had class for 100 minutes three times a week, the experimental group did the activity six times for two weeks. The control group was taught the textbook verbatim. The two groups were given the task of writing a paragraph again as a post-test. The paragraphs were evaluated. At 5\% significance levels, two-tailed test was applied. The scores of the control group were much lower than the experimental group in the paragraph writing test. The statistics also showed significant differences between mean scores of the two groups. The results prove the effectiveness of six thinking hats activity in developing writing skills of university students. Therefore, the present study recommends that it is appropriate for EFL teachers in Saudi Arabia to make students do the six thinking hats activity along with other activities given in the textbook in order to improve their writing skills.
\end{abstract}

Keywords: effectiveness, EFL learners, paragraph writing skills, teaching through activities, thinking hats

\section{Introduction}

\subsection{Background}

The major trait that distinguishes humans from the other species is language. It is used to share human feelings, emotions, thoughts, and ideas with each other (Chang \& Wu, 2002). In the story of evolution, if human beings have advanced far ahead of animals, it is mainly because of their ability to use language. A number of languages are born depending upon the geographical location, religion, race and other factors. Communication between people who speak different languages is not easily possible. It is only a common language which helps people to freely interact and stay connected.

English has proved itself to be the best language to serve as the lingua franca of the world. It is spoken today almost in all the countries and regarded as a world language (Crystal, 2003). In many Asian countries, such as India and Pakistan, English has gained greater respect than even the national languages. Command of English is taken as a sign of one's intelligence and educational attainment. In this day and age thus, success is measured in terms of one's competence in English, among other things. Development has become synonymous with English (Krashen, 2003). To mark themselves off as distinct and far removed from the common people, a large majority of the elites in the former British colonies speak only in English in preference to their mother tongue. In schools, colleges and universities too, the medium of instruction is English. Job interviews are conducted in English and employees use it in the work places. Success has become synonymous with English.

The situation is not vastly different in Saudi Arabia. There is a positive wave among the Saudi citizens towards learning and using English (Saudi Gazette, 2012). The youth of Saudi Arabia have realized the importance of English, and so they often go to the United States of America or the United Kingdom and learn English there, 
sometimes for years. Although Arabic enjoys the status of an international language, increasing numbers of people are using English in Saudi Arabia for different purposes and in different contexts. In many schools and colleges, English has become the medium of instruction just like in India and Pakistan. As Dearden (2014) avers, proficiency in the English language is the basic requirement in any job interview and the employees with better language skills dominate the job market. The signboards in the streets, traffic signals on the roads and names of shops are being written in English along with Arabic. A significant percentage of the Saudi people admit that economic prosperity of the country depends to a large extent on their knowledge of English.

Writing is a test for the cognition levels of the writer as it involves the capacity to think, language ability and strength of memory (Kellogg, 2001). It is viewed as an art which can be improved continuously. In today's world of digital technology, much emphasis is laid on written communication. In the work places, all the work is written in the form of reports (Brandt, 2005). All formal documents such as property documents and business contracts are written. The history of people, nations, and the world at large is stored by writing it down in books. In educational institutions too, most exams are primarily written tests. Therefore, writing skills are mandatory for one's success as a student as well as an employee (Geiser \& Studley, 2001).

\subsection{The Current Status of English in Prince Sattam Bin Abdulaziz University (PSAU)}

The students of Engineering, Medicine and Pharmacy, who are admitted in PSAU, study the English courses Listening and Speaking, Reading, Writing, and Grammar in the College of Preparatory Year Program (PYP) for two semesters and then go to their main stream. But it is a different scenario in the College of Business Administration, Kharj (CBAK). The students who opt for studying Business Administration, study English courses in CBAK itself. To enable the students to acquire English language skills, the following six courses are offered.

Table 1. English courses taught in CBAK

\begin{tabular}{lll}
\hline Level & Name of the Course & Prerequisites \\
\hline Level 1 & Grammar (NAJM 161) & None \\
& Reading (NAJM 162) & None \\
& Writing (NAJM 163) & None \\
Level 2 & Listening and Speaking (NAJM 165) & Grammar (NAJM 161) \\
& Reading in Business (NAJM 166) & Grammar (NAJM161), Reading (NAJM 162), \\
& & Writing (NAJM 163) \\
& Technical Writing in Business (NAJM 167) & Grammar (NAJM161), Reading (NAJM 162), \\
& & Writing (NAJM 163) \\
\hline
\end{tabular}

\subsection{The Problem of Teaching Writing to CBAK Students}

The authors invariably note the weak English language skills upon interacting with the students. The origin of this problem can be traced to school education, and it has been well documented. Alhawsawi (2013) states that teachers in the school use the bilingual method and teach English in Arabic possibly because of their own lack of language skills, or perhaps to make their job relatively easy. As a result, the students are not exposed to English all that much and it obviously hinders their performance (Fareh, 2010). School teachers deliver lectures using the lecture method disregarding the value of student participation. The classes tend to be teacher-centered rather than student-centered (Ahmed, 2014). Some teachers translate the entire lesson from English to Arabic following the Grammar Translation Method (GTM) adversely affecting the communicative competence of the students (Alfahadi, 2014). In most classes, students remain silent and inactive. Teaching aids such as audio visual equipment, educational videos, smart boards, language labs, internet, computer and voice recorders are not always provided in the classes; and where they are provided, they don't always function properly because of non-availability of technical staff (Almutairi, 2008). As a result, students are not trained to carry out any language function in English. Even when they graduate from secondary school, they do not often have the required language skills to write or speak simple sentences in English (Alshumaimeri, 2003).

When these students join the university, a large number of them find it very difficult to understand English spoken by professors in the beginning of the first semester. Owing to the concerted efforts of the language instructors, they get exposed to English and begin to eventually use it little by little. The researchers observed the following problems experienced by the students while writing:

1) Students are not aware of brainstorming techniques. 
2) They do not involve themselves much when the teacher carries out brainstorming to gather ideas. The teacher himself comes up with ideas and writes them on the board. The students remain inactive during the session and when they write their paragraphs, they do not make use of the points written by the teacher.

3) Many a time, the students prefer to take a photograph of what is written on the board using their mobile phones. This leads to lack of writing practice. Eventually, this results in their finding it difficult to write all the answers in the exams within the stipulated time.

4) Many students do not do their homework because no help is usually forthcoming from their family members who also do not know English.

5) Students are very often not aware of words and phrases so as to write about social issues. Their vocabulary is severely limited.

Keeping in view the above problems, the researchers have designed an activity based on Edward de Bono's six thinking hats (1985). This activity enables the participants to look at an issue and discuss it from six different perspectives. It is frequently used in the corporate world to resolve issues. Rob Barbaro, the former president of Prudential Insurance, used this activity regularly involving all his employees. In the European branches of Siemens, about 35 instructors, who are certified as six hats experts, are currently rendering their services. In the USA, Boeing is known for utilizing this activity. Companies such as Motorola, Honeywell, Cargill, Eli Lilly, National Semiconductor and Fidelity Investments use it extensively (Six Thinking Hats, 2019). In the academic context, it is being increasingly used as a teaching and learning tool. This kind of activities help students use the target language and learn it faster. Students enjoy doing activities in the class that enhance their learning. Education becomes a pleasant experience when students take active part in the classroom.

The purpose of the present study is to evaluate the effect of six thinking hats activity on improving university students' writing skills. In other words, it intends to find out whether the six thinking hats activity has any effect on developing paragraph writing skills of students of Prince Sattam Bin Abdulaziz University, Saudi Arabia. The rationale to focus on the paragraph writing and not the other forms of writing such as essay is that paragraph writing forms part of the course on Writing (NAJM 163). The students are expected to write opinion paragraphs using a topic sentence, at least three supporting sentences, details and a concluding sentence.

\section{Literature Review}

As described by Nunan (2004), there are two kinds of tasks. The first one is a real-world task using which the students employ language in everyday social contexts. The second one is a pedagogical task which engages the students in the classroom context and makes them use the target language. The six thinking hats activity falls under the second category of tasks. This activity was based on Edward de Bono's (1985) Six Thinking Hats model. It enables different types of thinking, makes the participants look at different aspects of the issue and draws conclusions (Gregory \& Masters, 2010).

During the activity, students brainstorm the given topic, look at the issue from different angles, discuss and debate various perspectives, use their intuition, exhibit their leadership skills and come to conclusions. As it is an activity, the class becomes very active and students will be the center of the class. When an activity is done in the class which results in learning, students would be committed to participate and get benefited (Krause, 2005). Students try to use the language they know to communicate. In the process, they accord importance to fluency. Accuracy of expression comes later. Corbett and Kearns (2003) opine that the focus has moved from teaching to learning in the system of education. This activity validates Kearns's opinion. It makes learners use the target language very effectively.

The six hats activity was used in 2015 by Majid and Nayfeh (2015) to study its effect on the 11th grade students in terms of improving their writing skills. The study proved that the six thinking hats method had a positive effective on the students. Dhanapal and Ling (2013) conducted an action research project to study the impact of six thinking hats in enhancing the learning of environmental studies. These researchers observed positive impact on the students' scholastic performance. In the research conducted by Ummu, Ismail and Margaretha (2017) on the effect of six thinking hats and critical thinking on speaking achievement, they found that the students had improved in terms of comprehension, pronunciation and fluency. Kivunja (2015), who carried out research on the effectiveness of the six thinking hats method, concluded that it can be used to teach critical thinking and problem solving in modern times.

A study was conducted by Altaua (2011) to find out the effectiveness of the six thinking hats on 5th grade students in the course of Arabic grammar. Fodah and Abdo (2005) conducted a study in order to determine the role of six thinking hats on fifth graders in developing creative thinking skills. In both the cases, the results were 
positive and encouraging. In order to compile and study the opinions of 6th, 7th and 8th grade school students, Koray (2005) interviewed 115 students using 15 Likert type items. The results showed that Pre-service Science teachers and the primary school students held positive opinions about the six thinking hats activity. A study was conducted on 217 male and female students in Jordan by Mofadi (2010). It showed that six thinking hats activity and multiple intelligences had improved $7^{\text {th }}$ graders' acquisition of scientific concepts.

In the above literature review, the researchers have observed that much of the research on six thinking hats was done on school students from 5th to 11th grades and the results had been encouraging in terms of learning of the students. Since six thinking hats activity has not been tested on university students, there is certainly a need to study its effectiveness on them. To fill this gap and to solve the problems of the Prince Sattam Bin Abdulaziz University students mentioned in 1.3 , the researchers have undertaken this task.

\section{Methodology}

\subsection{Participant (Subject) Characteristics}

Prince Sattam Bin Abdulaziz University in Al Kharj is situated $80 \mathrm{~km}$ away from Riyadh, the capital city of Saudi Arabia. A big number of students from Riyadh are admitted to the university and they commute daily from there. The other students hail from Al Kharj, Dhilam, Al Hota and other nearby towns. There are also a few foreign students from Sudan, Syria, Burma and Yemen but they are settlers in Saudi Arabia from long time ago. The students of Technical Writing in Business (NAJM 167) course were the subjects of the present study. There were five sections of this course in all.

Two sections of the Level 2 English course Technical Writing in Business were selected randomly. The experimental group was section 2114 and control group was section 2135. Section 2114 had 42 students and section 2135 had 38 students. Both the sections were selected randomly from the Technical Writing in Business course. The students of these two sections were considered as the sample for the study. Put together the two sections included a total of 80 students. The experimental group (Section 2114) consisted of 42 students, and they were taught through six hats activity. While the control group (Section 2135) was taught the same part of the textbook through traditional methods.

Table 2. Control and experimental groups sample selection

\begin{tabular}{llll}
\hline Group & Students' Age & Frequency of Students & Percentage \\
\hline Control Group & $17-18$ years & 23 & $60.52 \%$ \\
& $18-19$ years & 11 & $28.94 \%$ \\
& $19-20$ years & 4 & $10.52 \%$ \\
Total & & 38 & $100 \%$ \\
Experimental Group & $17-18$ years & 14 & $33.33 \%$ \\
& $18-19$ years & 21 & $50 \%$ \\
& $19-20$ years & 7 & $16.66 \%$ \\
Total & & 42 & $100 \%$ \\
\hline
\end{tabular}

The present study was conducted in order to investigate the effect of six thinking hats activity in developing paragraph writing skills of university students. The activity has three phases, namely pre-task, while task and post-task. In the pre-task stage, the students along with the instructor do brainstorming for the topic. In the while task stage, students discuss the topic and make notes on a colored A4 sheet of paper. In the post-task stage, each student writes his own paragraph using the notes on the other side of the A4 sheet. The average age of the students was seventeen to eighteen (17-18) years and the sections under study were homogeneous. From the experimental group 37 (88\%) students came from Level 1 who passed three Level 1 courses, namely Grammar (NAJM 161), Reading (NAJM 162) and Writing (NAJM 163) and 5 (12\%) were repeaters of the course. In the control group 31 (82\%) came from Level 1 just like experimental group students and $7(18 \%)$ were repeaters.

\subsection{Lesson Plan}

In the present study, a lesson plan model was designed and adopted by the researchers in keeping with the need and context. The students of the class were divided into six groups and each group was assigned a color. To identify the color, all the students brought a cap that identified their team and wore it during the activity. They also brought A4 sheets of paper as per their team color and, as the activity was in progress, they wrote their points, ideas and counter arguments on that sheet.

The duration of every English class was 100 minutes. This activity was done in the first 30 minutes of the class. 
The remaining 70 minutes were set apart for learning using the textbook.

Table 3. Six thinking hats activity-based lesson plan model

Blue hat collects the topic from the client (the teacher) and explains it to the group. As the others discuss the topic, the students in the blue hat act like the managers and control and monitor the discussion. They take the final decision based on the discussion.

\section{$\downarrow$}
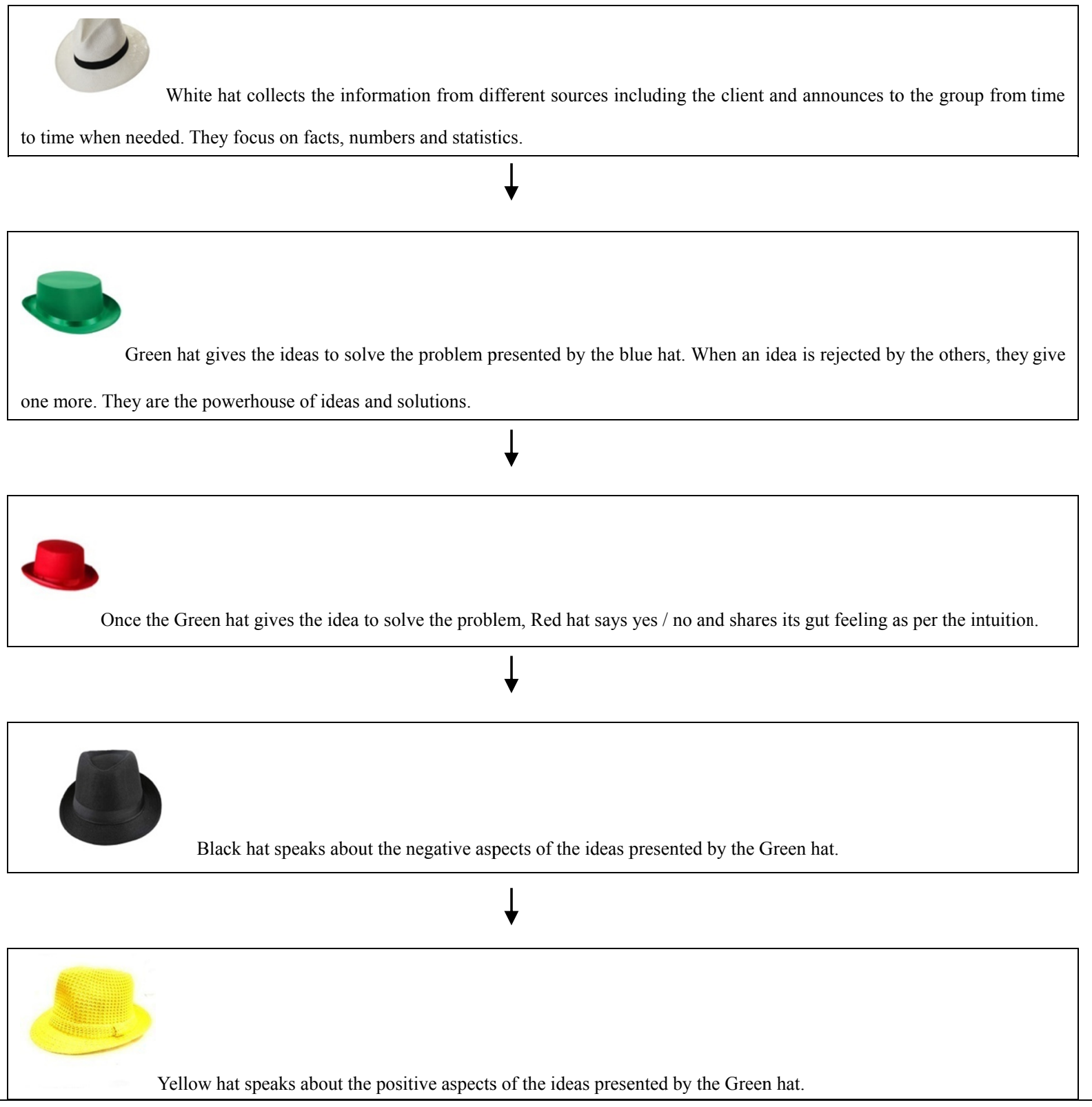

Based on the above lesson plan, the following topics were discussed one in each class:

1) First class: Should women drive cars in the Kingdom of Saudi Arabia? 
2) Second class: Should there be only one language in the world?

3) Third class: Should there be film industry in KSA?

4) Fourth class: Should English be the medium of instruction in KSA?

5) Fifth class: Should there be social media?

6) Sixth class: Should there be sports in the university?

After the activities, all were asked to write a paragraph each on the reverse of the sheet of paper using the points they had already written down.

Table 4. Different types of paragraphs written based on the color of the hat

\begin{tabular}{ll}
\hline Color of the Hat & Type of Paragraphs Written \\
\hline White & The paragraphs include all the facts, numbers, calculations, statistics, etc. \\
Green & The paragraphs speak about ideas, creative solutions to the problems, new perspectives, etc. \\
Red & The paragraphs speak about intuition or gut feelings. These paragraphs do not explain the logic behind the decisions. \\
Black & The paragraphs focus on negative aspect of ideas, provide criticism, sound pessimistic, etc. \\
Yellow & The paragraphs sound optimistic about the ideas and speak about the positive side of the solutions presented. \\
Blue & The paragraphs speak about the decisions or conclusions. \\
\hline
\end{tabular}

Students write these paragraphs and read them to the class. In the next class, the teams are given a different color and students write paragraphs from different perspective. In this manner, every student writes six types of paragraphs. All these paragraphs are evaluated and feedback is given to the students.

Before doing the study, the students of both groups were given a paragraph writing test to find out the difference in their mean scores. To evaluate the paragraphs of the pre-test and the post-test, a committee of three senior faculty members, who were teaching English at the College of Business Administration, was constituted. The researchers, along with the committee members, prepared a rubric for evaluating the paragraphs applying the criteria laid down in the textbook (see Appendix A for the rubric). The paragraphs were evaluated for 10 marks using the rubric. The average of the scores given by the three faculty members was taken as the final score. By applying inferential statistics techniques, scores of pre-test were calculated and compared with each other. After doing pre-test, the experimental group was introduced to six thinking hats and, after each time the activity was done, the students wrote a paragraph based on the notes they had written on their colored A4 sheet. The teacher gave feedback on their paragraphs. The control group students did not do this activity in the class. They were taught the textbook and asked to write paragraphs as practice. The teacher gave feedback on those paragraphs. At the end of the six classes, the two groups of students were administered the same paragraph writing test as post-test (see Appendices B, C, D and E for the sample paragraphs). The same syllabus was taught by the teachers of both the groups. The only difference was that, in one section, before practicing to write the paragraph, six hats activity was conducted. The activity was conducted six times, and each time the students shifted their hats.

\subsection{Research Design}

The research design was as follows:

A pretest-posttest control is proposed. Here the treatment is done only on the experimental group though the post-test measures are done for both the control group and the experimental group.

EG: $\quad \mathrm{R} \quad \mathrm{O} 1 \quad \mathrm{X} \quad \mathrm{O} 2$

CG: $\quad \mathrm{R} \quad \mathrm{O} 3 \quad \mathrm{O} 4$

The treatment effect is $(\mathrm{O} 2-\mathrm{O} 1)-(\mathrm{O} 4-\mathrm{O} 3)$

Where EG is experimental group; CG is control group; O's are the samples, $\mathrm{X}$ is the experiment; and $\mathrm{R}$ is randomization.

The researchers made a paragraph writing test comprising a topic sentence, supporting sentences, details and a concluding sentence. There was a topic based on which students wrote a complete paragraph. The test was conducted as a pre-test and post-test. Pre-test and post-test marks were collected from experimental and control groups. An instrument of writing skill test consisting five items was used. The quantitative data of pre-test and post-test were analyzed by using the Statistical Packages for Social Sciences (SPSS) 26.0. Mean and standard deviations were calculated and two tailed t-test was applied. Inferential statistics of paired sample $t$ test was used 
to examine the difference between the participants' mean scores of both the groups. The t-Test statistics for paired-sample test is:

$$
t=\frac{\bar{d}-\mu_{d}}{s_{d} / \sqrt{n}}
$$

Where $\overline{\mathrm{d}}$ is mean paired difference; $\mu_{\mathrm{d}}$ is hypothesized difference; $\mathrm{s}_{\mathrm{d}}$ is sample standard deviation; $\mathrm{n}$ is the number of paired values in the sample. The results are interpreted on the basis of p-value approach at $5 \%$ level of significance. This implies that, if the significance value is less than 0.05 , the null hypothesis is not accepted and vice versa. Also, before performing the paired sample t-test, Levene's test for homogeneity of variance is conducted which is a necessary condition to perform t-test, or else other non-parametric tests have to be used.

\section{Analysis}

The chief purpose of the study was to assess the usefulness of conducting six thinking hats activity in writing paragraphs. As per the question of the study, the results are displayed. The following Figure 1 compares the scores of pre-test and post-test of the experimental group (2114) and control group (2135).

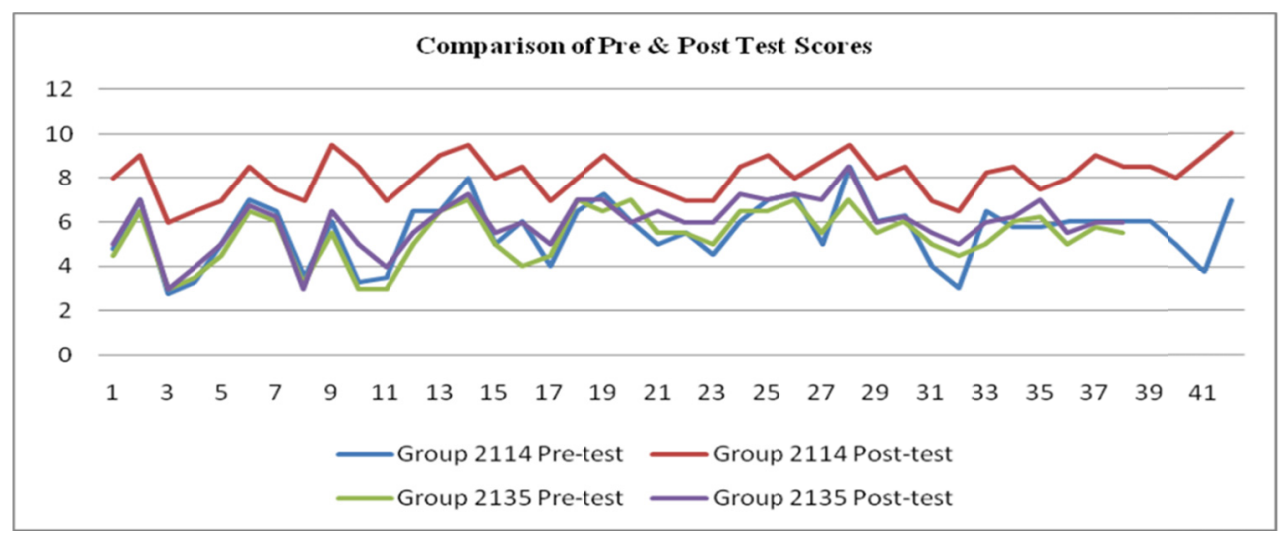

Figure 1. Comparison of pre-test \& post-test scores of experimental group (2114) and control group (2135)

Figure 1 depicts the experimental and control groups' pre- and post-test scores. It clearly shows that the post-test scores of the experimental group are higher than the control group's post-test scores. It is evident from Figure 1 that there is not much difference between the control group's pre-test and post-test scores. The traditional methods used in the control group failed to produce satisfactory results; whereas, six thinking hats activity was able to make the experimental group students score high marks.

The following Figure 2 shows the performance of both the groups before and after conducting the activity.

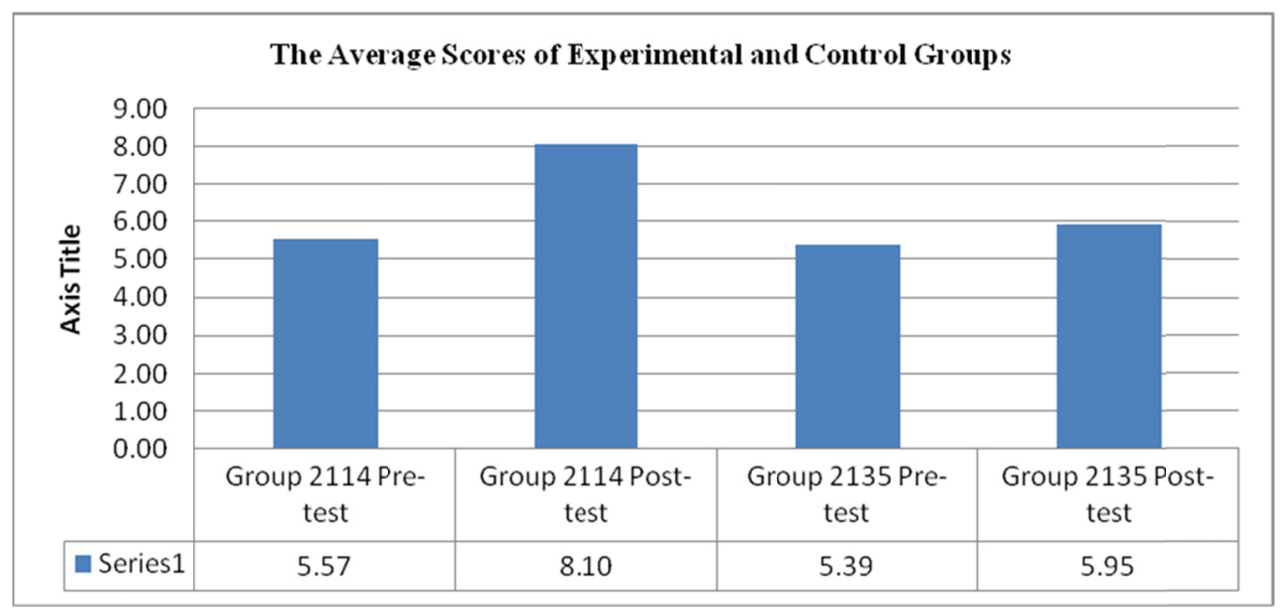

Figure 2. The average of pre-test and post-test scores of experimental and control groups 
Figure 2 shows that average of pre-test of the experimental group is 5.57 while it 5.39 for the control group. It means that the levels of experimental and control groups are almost similar before conducting the activity. The students of both the groups possessed similar paragraph writing skills. But after conducting the six thinking hats activity for the experimental group, the average performance rose to 8.10. This is a big difference. As a group, the students improved their paragraph writing skills. In the control group, the average of post-test is 5.95 , which means there is not much difference between the scores of pre- and post-tests. It is clear from the above graph that paragraph writing skills of control group have not improved all that much. Using the Statistical Package for the Social Sciences (SPSS) the data collected from both pre-test and post-test were analyzed for both the groups.

Table 5. Results of hypotheses tested

\begin{tabular}{lll}
\hline & Levene's test & Sig.(2-tailed) \\
\hline Homogeneity of Variances & 2.39 & 0.07 \\
& t-statistic & Sig.(2-tailed) \\
Pre-test results of Control and Experimental group & 0.62 & 1.99 \\
Pre-test and post-test results between Control and Experimental groups & 10.76 & 0.00 \\
\hline
\end{tabular}

Source: Author's calculation.

First, Levene's test for homogeneity of variances is performed. Here the null hypothesis is that the variances are homogeneous and the alternate hypothesis is that the variances are not homogeneous. All the p-value of Levene's test is more than 0.05 ; hence, it is inferred that the variances are homogenous.

The next hypothesis is regarding the mean scores of paragraph writing of pre-test for control and experimental groups. The control group's mean score was 5.3882 and for the experimental group the mean score was 5 . The scores of both the groups are relatively similar in the pre-test. Here the null hypothesis is that there is no significant difference in the pre-test mean scores of both the groups. Statistical testing reveals no significant difference between the mean scores for both the groups as the p-value is 1.99. This indicates that both the groups are almost similar when it comes to paragraph writing.

Finally, the difference in pre-test and post-test results between control and experimental groups is tested. The mean of the difference between the pre-test and post-test of the control group was 0.56 , while the mean of the difference between the pre-test and the post-test of the experimental group was 2.52 . Here the null hypothesis is that there is no significant difference between the mean scores of control and experimental groups. As the p-value is 0.000 which is less than 0.05 ; hence, the null hypothesis is rejected. It proves that there is a major difference in post-test between the control and experimental groups. The mean score of the experimental group (2.52) is more than that of the control group (0.56), hence it is inferred that conducting six thinking hats activity has increased the paragraph writing skills of the students.

\section{Discussion}

The study was done with the intention of finding out the effectiveness of six thinking hats in improving language skills. The findings show that the activity plays a considerable role in developing writing skills of university students. The results very clearly demonstrate that the experimental group experienced overall positive effect on writing skills when compared to the control group students. The results are based upon pretest-posttest control group design to find out whether six thinking hats activity has any impact on developing paragraph writing skills of university students in Saudi Arabia. The outcome of this study indicates that the students who were taught paragraph writing through six thinking hats learnt and performed better than the control group students. It means that lecture method and Grammar Translation Method are not exactly suitable to teach writing skills. A probable reason could be that, in these traditional methods, teachers become self-centered and students perform very little.

The six thinking hats activity was able to solve the problems mentioned in section 1.3 of the article. The post-test results show that the experimental group students have understood the importance of brainstorming before writing a paragraph. This awareness enabled them to look at the topic from different angles and gain overall understanding of the topic. Unlike the control group, the students of the experimental group got deeply involved in the activity and brainstorming was spontaneously done. The teacher was not required to write points on the board. The students themselves wrote points for discussion on their A4 sheets. To restrain students from taking photos of the board, cameras and cell phones were not allowed to be used during the activity. The students thus had the only option of writing down their notes on the A4 sheets. This exercise gave them writing practice. As a result, they were able to attempt all the questions in the exams without complaining that the time given was not sufficient. The students of the experimental group did their writing homework with relative ease since they no 
longer felt the need to take the help of family members or others at home. Having already learnt how to look at and understand the given topic during the experiment, they were able to apply the principles of six hats to other topics as well. As the students discussed and wrote the points, the problem of insufficient vocabulary too was solved. They were able to collect words and phrases needed to write the paragraph from their discussions. When the students could not find appropriate words, the teacher did scaffolding and helped them with the required vocabulary.

\subsection{Limitations}

The following are the some of the limitations of this method:

- As there are six groups of students, it is somewhat difficult to control them from cross talking and, when many students speak simultaneously, it creates a commotion.

- The weak and the shy students do not contribute as much as the active students.

- Some students, who do not understand their roles, speak for the other hats which leads to confusion of roles.

- At times, code switching and code mixing happens as the students are in an EFL context. Some students use only Arabic to express their ideas.

\subsection{Further Recommendations}

The following are the recommendations for future research:

- Research can be done to find out how this activity helps develop other forms of writing as well as listening and speaking.

- This research was done in the EFL context. The same can be done in an ESL context too to find out the effectiveness of this activity.

- This activity was done for the students of a college business administration. It can be conducted for the students of medicine and engineering streams as well.

\section{Conclusion}

The present study was conducted to examine the effect of six thinking hats on paragraph writing skills of university students. The results are in line with studies on De Bono's Six Thinking Hats by Belfer K (2001), Dhanapal and Ling (2013), Al-Khataybeh and Al-Tarawneh (2015), Ummu, Ismail and Margaretha (2017), Kivunja (2015), Altaua (2011), Fodah and Abdo (2005), Koray (2005) and Mofadi (2010). The results prove that six thinking hats activity helped students think about a topic from different perspectives and write better paragraphs. This enhanced their active participation in the class and helped create a lively atmosphere. As the main aim is to communicate by writing, this activity made them, first of all to think from various points of view and organize their ideas. The researchers viewed errors of writing in terms of spelling and punctuation as common and natural and focused on the organization of ideas and conveying meaning rather than correction of errors. The experimental group's score was noticeably higher than that of the control group after they were exposed to six hats activity.

Six hats activity significantly helped students in looking at an issue from different angles, organize ideas and draw conclusions. Reluctance to write was defeated to a great extent. Students became more confident in terms of understanding the topics and they seemed to enjoy the process of six thinking hats activity. Finally, it is perhaps appropriate to claim, in view of the evidence provided by the research, that the six thinking hats activity is effective in developing paragraph writing skills of university students of Saudi Arabia. The researchers recommend that this activity may be initiated in the universities of Saudi Arabia to enhance students' writing skills. It can also be effectively used to improve thinking and speaking skills of students. Further, it has the potential to make the participants think along creative lines and draw logical conclusions.

\section{Acknowledgments}

We would like to express our gratitude to the management of Prince Sattam Bin Abdulaziz University for encouraging and supporting us to do research. We also thank our colleagues and students who extended their unstinted support by participating in the formal and informal discussions regarding the paper.

\section{References}

Ahmad, A. M. (2014). Kumaravadivelu's Framework as a Basis for Improving English Language Teaching in Saudi Arabia: Opportunities and Challenges. English Language Teaching, 7(4), 96-110. 
https://doi.org/10.5539/elt.v7n4p96

Alfahadi, A. (2014). Saudi teachers' views on appropriate cultural models for EFL textbooks: Insights into TESOL teachers' management of global cultural flows and local realities in their teaching worlds. Unpublished doctoral dissertation, University of Exeter, Exeter, UK.

Alhawsawi, S. (2013). Investigating student experiences of learning English as a foreign language in a preparatory programme in a Saudi university. Unpublished doctoral dissertation, University of Sussex, Brighton, UK.

Al-Khataybeh, M., Al-Kerak, M., \& Nayfeh, S. A. (2015). The Effect of Using the Six Thinking Hats Method on the Development of EFL Female Eleventh Grade Students' Writing Skill in Southern Al- Mazar Directorate of Education. International Journal of Arts and Humanities, 1(4), 24-37. Retrieved from https://www.researchgate.net/publication/328192086_The_Effect_of_Using_the_Six_Thinking_Hats_Meth od_on_the_Development_of_EFL_Female_Eleventh_Grade_Students'_Writing_Skill_in_Southern_Al-Ma zar_Directorate_of_Education

Almutairi, N. H. (2008). The influence of educational and sociocultural factors on the learning styles and strategies of female students in Saudi Arabia. Unpublished doctoral dissertation, University of Leicester, Leicester, UK.

Al-Seghayer, K. (2012, December 11). Status and functions of English in Saudi Arabia. Saudi Gazette, Retrieved from http://saudigazette.com.sa/article/24861

Al-Shumaimeri, Y. A. N. (2003). A study of classroom exposure to oral pedagogic tasks in relation to the motivation and performance of Saudi secondary learners of English in a context of potential curriculum reform. Unpublished Ph.D. Thesis, University of Leeds, Leeds.

Altaua, I. (2011). The effect of using the six thinking hats on the fifth elementary grade students in the Arabic language grammar. Unpublished Master's Thesis, Al-kerak Mu'tah University, Mu'tah, Jordan.

Belfer, K. (2001). De Bono's six thinking hats technique: A metaphorical model of communication in computer mediated classrooms. In C. Montgomerie \& J. Viteli (Eds.), Proceedings of ED-MEDIA 2001--World Conference on Educational Multimedia, Hypermedia \& Telecommunications (pp. 113-116). Norfolk, VA USA: Association for the Advancement of Computing in Education (AACE). Retrieved May 12, 2019 from https://www.learntechlib.org/primary/p/8346/

Brandt, D. (2005). Writing for a Living: Literacy and the Knowledge Economy. Written Communication, 22, 166-197. https://doi.org/10.1177/0741088305275218

Chang, C., \& Wu, C. F. (2002). Perplexed age of English learning; Using critical period. Cambridge, England: Cambridge University Press.

Corbett, R., \& Kearns, J. (2003). Implementing activity-based e-learning. A preconference workshop in the TCC 2003. Retrieved from http://www.ucalgary.ca/-corbett/virtual_instructors/index.htm

Creswell, J. W. (2009). Research design: Qualitative, quantitative, and mixed methods approaches (3rd ed.). Los Angeles: Sage.

Crystal, D. (2003). English as a global language. Cambridge, England: Cambridge University Press. https://doi.org/10.1017/CBO9780511486999

De Bono, E. (1985). Six thinking hats. London: Penguin.

Dearden, J. (2014). English as a medium of instruction - a growing global phenomenon. British Council. Retrieved from https://www.britishcouncil.es/sites/default/files/british_council_english_as_a_medium_of_instruction.pdf

Dhanapal, S., \& Ling, T. K. (2013). A Study to Investigate How Six Thinking Hats Enhance the Learning of Environmental Studies. IOSR Journal of Research \& Method in Education (IOSR-JRME), 1(6), 20-29. https://doi.org/10.9790/7388-0162029

Fareh, S. (2010). Challenges of Teaching English in the Arab world: Why can't EFL Programs Deliver as Expected? Procedia-Social and Behavioral Sciences, 2(2), 3600-3604. https://doi.org/10.1016/j.sbspro.2010.03.559

Fodah, A., \& Abdo. Y. (2005). The Effect of Using De Bono's Six Thinking Hats in Teaching Science on the Developing of Creative Thinking Skills' Tendencies on Fifth Graders. Scientific Education Journal, 4, 
$2720-2820$.

Geiser, S., \& Studley, R. (2002). UC and the SAT: Predictive Validity and Differential Impact of the SAT I and SAT II at the University of California. Educational Assessment, 8(1), 1-26, https://doi.org/10.1207/S15326977EA0801_01

Gregory, S., \& Masters, Y. (2010, March). Six hats in Second Life: Enhancing preservice teacher learning in a virtual world. Paper presented at the International Conference on Teaching and Learning with Technology, Singapore, 2-6 March. $\quad$ Retrieved from http://www.virtualclassrooms.info/papers/Six\%20Hats\%20in\%20Second\%20Life.pdf

Hani, U., Petrus, I., \& Margaretha, D. S. (2017). The Effect of Six Thinking Hats and Critical Thinking on Speaking Achievement (pp. 85-88). Advances in Social Science, Education and Humanities Research (ASSEHR), 82, 9th International Conference on Applied Linguistics (CONAPLIN 9). https://doi.org/10.2991/conaplin-16.2017.18

Kellogg, R. T. (2001). Long-Term Working Memory in Text Production. Memory \& Cognition, 29(1), 43-52. https://doi.org/10.3758/BF03195739

Kivunja, C. (2015) Using De Bono's Six Thinking Hats Model to Teach Critical Thinking and Problem-Solving Skills Essential for Success in the 21st Century Economy. Creative Education, 6, 380-391. https://doi.org/10.4236/ce.2015.63037

Koray, O. (2005). Students' Perceptions about Using Six Thinking Hats and Attribute Listing Techniques in the Science Course. Educational Administration: Theory \& Practice, 43, 379-400.

Krashen, S. (2003). Dealing with English fever. Selected papers from the Twelfth International Symposium on English Teaching/English Teachers'Association (pp. 100-108). ROC, Taipei, Crane.

Krause, K. L. (2005). Understanding and promoting student engagement in university learning communities. Melbourne: Centre for the Study of Higher Education. The University of Melbourne. Retrieved from https://www.liberty.edu/media/3425/teaching_resources/Stud_eng.pdf

Mofadi, K. (2010). The effect of science instruction by multiple-intelligences and six hats strategies on seventh graders' scientific concepts and thinking skills acquisition. Unpublished PhD. Dissertation, Yarmouk University, Irbid, Jordan.

Nunan, D. (2004). Task-based language teaching. Cambridge, UK: Cambridge University Press. https://doi.org/10.1017/CBO9780511667336

Six Thinking Hats. (2019, May 20). Retrieved from https://www.edwdebono.com/six-thinking-hats

\section{Appendix A}

Rubric for Evaluating the Paragraphs

\begin{tabular}{|c|c|c|c|c|}
\hline & 2 Marks & 1.5 Marks & 1 Mark & 0.5 Mark \\
\hline Topic Sentence & $\begin{array}{l}\text { Main idea is stated clearly in } \\
\text { the opening sentence. Correct } \\
\text { sentence structure is used. }\end{array}$ & $\begin{array}{l}\text { Main idea is stated } \\
\text { clearly in the opening } \\
\text { sentence. Sentence } \\
\text { structure is not correct. }\end{array}$ & $\begin{array}{l}\text { Main idea is not clear but } \\
\text { the sentence structure is } \\
\text { correct. }\end{array}$ & $\begin{array}{l}\text { Main idea is not clear } \\
\text { and wrong sentence } \\
\text { structure is used. }\end{array}$ \\
\hline $\begin{array}{l}\text { Supporting } \\
\text { Sentences }\end{array}$ & $\begin{array}{l}\text { Minimum } 3 \text { supporting } \\
\text { sentences are written and all } \\
\text { are well connected to the } \\
\text { topic. }\end{array}$ & $\begin{array}{l}\text { Only } 2 \text { supporting } \\
\text { sentences are connected } \\
\text { to the topic and others } \\
\text { are not connected. }\end{array}$ & $\begin{array}{l}\text { Only one supporting } \\
\text { sentence is connected to } \\
\text { the topic and others are } \\
\text { not connected. }\end{array}$ & $\begin{array}{l}\text { None of the supporting } \\
\text { sentences are connected } \\
\text { to the topic. }\end{array}$ \\
\hline $\begin{array}{l}\text { Concluding } \\
\text { Sentence }\end{array}$ & $\begin{array}{l}\text { The concluding sentence } \\
\text { restates the main idea of the } \\
\text { paragraph appropriately. }\end{array}$ & $\begin{array}{l}\text { The concluding sentence } \\
\text { restates the main idea of } \\
\text { the paragraph. }\end{array}$ & $\begin{array}{l}\text { The concluding sentence } \\
\text { is not well connected to } \\
\text { the main idea. }\end{array}$ & $\begin{array}{l}\text { There is no concluding } \\
\text { sentence. }\end{array}$ \\
\hline Spellings & $0-2$ spelling errors exist. & 3-4 spelling errors exist. & 5-6 spelling errors exist. & $\begin{array}{l}6 \text { and more than } 6 \\
\text { spelling errors exist. }\end{array}$ \\
\hline $\begin{array}{l}\text { Grammar and } \\
\text { Punctuation / } \\
\text { Capitalization }\end{array}$ & $\begin{array}{l}0-2 \text { errors in grammar, } \\
\text { punctuation and capitalization. }\end{array}$ & $\begin{array}{l}\text { 3-4 errors in grammar, } \\
\text { punctuation and } \\
\text { capitalization. }\end{array}$ & $\begin{array}{l}5-6 \text { errors in grammar, } \\
\text { punctuation and } \\
\text { capitalization. }\end{array}$ & $\begin{array}{l}\text { More than } 6 \text { errors in } \\
\text { grammar, punctuation } \\
\text { and capitalization. }\end{array}$ \\
\hline
\end{tabular}

\section{Appendix B}




\section{An Example of Control Group Pre-test Paragraph}

\section{What makes you laugh?}

Excellent question. you couldn't have said iTbeTTer! laughter is the best medicine, after all. one of my mates, Neel kolhatkar (Neel k on you Tube) is a stand up comedion and Ive been to a number of his shows. but then as a nanpo viral videos youtube That $i$ like to watch.

\section{Appendix C}

\section{An Example of Control Group Post-test Paragraph}

\section{What makes you laugh?}

I need laughter. The day is not good if I don't laugh. I laugh for tv shows more. I like them. What a laugh. My father is a joker. He makes me laugh. My Frineds make me laugh every day. They are good. I like stand up comedy but it is not there in my place. Cartoons are good. They make me laugh. Everything makes me laugh.

\section{Appendix D}

\section{An Example of Experimental Group Pre-test Paragraph}

\section{Why is vacation important?}

It is the season to start Planning your next vacation Now you may not think That IT is a proiority but you'd be wrong. There are Plenty of reasons To Plan a vacation each and every year. but were narrow down The five most important ones. read on and the take action by clicking the Plan your vacation.

\section{Appendix E}

\section{An Example of Experimental Group Post-test Paragraph}

\section{Why is vacation important?}

Vacations are important for many reasons as they are good for our health, family and studies. First of all, we can really relax and sleep better because we are not thinking about schedules and studies. People need time to change routine. Also, our families connect better as we are not busy and worried about what is next. Vacations bring people together. They become more social. Vacations help them visit new places. People can go to the beach and use the vacations for sightseeing. Finally, we come back to college with better and more active mind. The reasons for taking vacations differ from one person to another.

\section{Copyrights}

Copyright for this article is retained by the author, with first publication rights granted to the journal.

This is an open-access article distributed under the terms and conditions of the Creative Commons Attribution license (http://creativecommons.org/licenses/by/4.0/). 